\title{
Proces Jana Kasprowicza we Wroclawiu w 1887 r.
}

Dnia 17 listopada 1887 r. Jan Kasprowicz - późniejszy wybitny polski poeta - został skazany przez sąd we Wrocławiu na karę pół roku więzienia. By zrozumieć, jak do tego doszło, trzeba cofnać się kilka, a co najmniej cztery lata. Kiedy to podczas studiów w Lipsku w połowie kwietnia 1884 r. poznał Ludwika Krzywickiego'. Dzięki niemu J. Kasprowicz po raz pierwszy zetknął się z doktryną socjalizmu naukowego. Członkowie bowiem stworzonej przez L. Krzywickiego socjalistycznej grupy młodzieżowej, do której należał także J. Kasprowicz, współpracowali z L. Krzywickim przy korekcie pierwszego tomu wydania w języku polskim Kapitału Karola Marksa, przygotowywanego przez tegoż Krzywickiego².

W sierpniu 1884 r. Jan Kasprowicz przeniósł się z Lipska do Wrocławia. Okres wrocławski - jak stwierdził to Roman Loth, biograf J. Kasprowicza był dla niego ,uniwersytetem życia"’3. Prawdziwymi powodami zmiany uniwersytetu przez niego była trudna sytuacja materialna, w jakiej znalazł się w Lipsku. Życie we Wrocławiu było po prostu tańsze niż w Lipsku

Dnia 17 listopada 1884 r. zapisał się na Wydział Filozoficzny z zamiarem studiowania historii ${ }^{5}$. W rzeczywistości najbardziej uczęszczał na wykłady z lite-

\footnotetext{
${ }^{1}$ R. Loth: Młodość Jana Kasprowicza. Szkic biograficzny. Poznań 1962, s. 74.

2 Jan Kasprowicz. Wstęp, wybór materiałów i przypisy R. Loth. Warszawa 1964, s. 324, przyp. 6.

${ }^{3}$ R. Loth: Młodość Jana Kasprowicza..., s. 87.

${ }^{4}$ M. Sosnowski: W zgodzie z bytem i przeznaczeniem. Rozważania o osobowości Jana Kasprowicza. Psychologiczny portret twórcy. Warszawa 2010, s. 126.

${ }^{5}$ Allgemeines Studenten-Register Philosophische Fakultät. Abgegangene Studenten. Vol. XXXIII. Archiwum Uniwersytetu Wrocławskiego, sygn. F 479, s. 88; Album der mit dem
} 
raturoznawstwa Władysława Nehringa, który był także kuratorem Towarzystwa Literacko-Słowiańskiego, do którego również należał i aktywnie w nim działał J. Kasprowicz ${ }^{6}$. Na forum Towarzystwa J. Kasprowicz uzewnętrzniał niekiedy swoje poglądy polityczne, krytykując szczególnie osoby znajdujące się w lepszej niż on sytuacji materialnej lub o innych przekonaniach. Nazywał między innymi Towarzystwo „zgrzybiałym”, a odnośnie do tematyki odczytów wygłoszonych na jego forum twierdzil, że zawiewa mu zeń „zaduch grobowy”. J. Kasprowicz miał ciężki w pożyciu charakter, jako jedyny krytycznie ocenił wystąpienie Andrzeja Szeptyckiego O dramacie Mickiewicza „Konfederaci barscy” wygłoszone w semestrze zimowym 1884/1885. O tym wystąpieniu później w liście do matki A. Szeptycki napisał, że nie wzbudziło ono żadnych kontrowersji wśród słuchaczy i tylko ,jeden z socjalistów oponował”. Zaś po wystąpieniu Józefa Prabuckiego (najlepszego przyjaciela A. Szeptyckiego) na temat przyczyn reformacji w Polsce J. Kasprowicz wygłosił tak kontrowersyjne i wzbudzające emocje poglądy, że przyjaciele J. Prabuckiego wystąpili nawet z wnioskiem o wykluczenie J. Kasprowicza z grona członków Towarzystwa?.

Oprócz studiów J. Kasprowicz zaangażował się także w działalność polityczną. Zaczął działać w legalnie działającym stowarzyszeniu Pacyfik (Pacific). Skupiało ono radykalną młodzież głoszącą poglądy socjalistyczne, pragnącą zmienić świat i jego niesprawiedliwe struktury ${ }^{8}$. Stowarzyszenie zostało założone w 1883 r. przez Gerharta Hauptmanna (wybitnego powieściopisarza niemieckiego, wówczas studenta wrocławskiej Królewskiej Szkoły Sztuki i Rzemiosł Artystycznych), jego brata Carla Hauptmanna, Alfreda Ploetza (studenta ekonomii) i lekarza Ferdynanda B. Simona (zięcia Augusta Ferdynanda Bebela, przywódcy niemieckiej socjaldemokracji). Celem stowarzyszenia początkowo było tworzenie socjalistycznych kolonii w Stanach Zjednoczonych'.

Zeugniss der Reife in der Philosophischen Fakultaet inscripten Studierenden, 23 IV 1885-28 X 1911. Archiwum Uniwersytetu Wrocławskiego, sygn. 435, s. 351.

${ }^{6}$ M. Sosnowski: $W$ zgodzie $z . . .$, s. $127-128$.

7 J. Koredczuk: Studia Andrzeja Szeptyckiego we Wrocławiu. W: Ślaska Republika Uczonych. Schlesische Gelehrtenrepublik. Slezska Vědecká Obec. Red. M. Hałub, A. Mańko-Matysiak. T. 5. Dresden-Wrocław 2012, s. 293-294. W kolejnym liście do matki A. Szeptycki napisał o nim: „Odczyt ten, a raczej dyskusja, którą wywołał, wiele nam krwi napsuła. Jeden z kochanych naszych socjalistów wyraził się bez uszanowania o kościele katolickim. Chcemy go zmusić do odwołania tego co powiedział". Zob. S. Wójtowicz: Wrocławskimi śladami metropolity Andrzeja Szeptyckiego. „Acta Universitatis Wratislaviensis” 2012, nr 3459. Slavica Wratislaviensa, T. 156, s. 57-58, cyt. za: Z. Szeptycka: Młodość i powołanie ojca Romana Andrzeja Szeptyckiego zakonu św. Bazylego Wielkiego. Wrocław 1993, s. 88.

${ }^{8}$ M. Sosnowski: Jan Kasprowicz. Opowieść biograficzna. Cz. 1: Chłopska sukmana (1860-1889). Zakopane 2015, s. 301.

${ }^{9}$ Ibidem, s. 262. 
Kasprowicz włączył się także bardzo czynnie w tajną działalność ruchu ,ikarijczyków"10, młodzieżowej organizacji socjalistycznej o charakterze utopijnym. Nazwa tego ruchu pochodzi od tytułu powieści Etienne Cabet - Podróż do Ikarii (Voyage en Icarie) ${ }^{11}$. Działalność „,irakijczyków” i stowarzyszenia Pacyfik łączyły niemalże tożsamy skład członkowski obydwu ruchów i głoszone hasła utopijno-socjalistyczne ${ }^{12}$.

Do ruchu tego został on wciągnięty przez nowo poznanego kolegę z Uniwersytetu, z którym się zaprzyjaźnił, studenta matematyki Henryka Luxa ${ }^{13}$. Jan Kasprowicz ukrywał u siebie uciekającego przed aresztowaniem z Warszawy Leona Ciesielskiego (ps. Chłop). Był on byłym działaczem organizacji miejskiej Wielkiego Proletariatu w Zgierzu, rozbitej przez policję w czerwcu 1886 r. po zamachu na konfidenta Franciszka Herszela ${ }^{14}$. Przybył do Wrocławia na początku 1886 r. jako emisariusz socjaldemokracji Królestwa Polskiego z misją nawiązania kontaktów z zagranicą, między innymi z wrocławskim socjalistycznym deputowanym do Reichstagu - Juliuszem Kräckerem. W zasadzie była to ucieczka przed aresztowaniem przez rosyjskie władze policyjne ${ }^{15}$. Kasprowicz załatwił L. Ciesielskiemu pomoc, dzięki której udało mu się przedostać do Szwajcarii ${ }^{16}$.

Na marginesie warto dodać, że członkom Wielkiego Proletariatu Wrocław nie był obcy. W 1878 i 1883 r. przebywał w nim Ludwik Waryński, w roku 1882 - Stanisław Kunicki, Feliks Kon i Stanisław Dąbski, a przed L. Waryńskim przebywali tu Samuel Diksztajn i Stanisław Mendelson ${ }^{17}$. Przez Wrocław najczęściej przemycano do Królestwa Polskiego materiały propagandowe i czcionki drukarskie.

Od czasu wydania $\mathrm{z}$ inicjatywy kanclerza Ottona von Bismarcka ustawodawstwa wyjątkowego przeciw socjalistom (ustawa z dnia 21 października 1878 r.), można powiedzieć, że wszelkie osoby w jakikolwiek sposób związane z ruchem socjalistycznym znalazły się na „celowniku władz pruskich” i w kręgu zainteresowania policji. Wprawdzie ustawa Przeciw powszechnie niebezpiecznym dązeniom socjalnej demokracji obowiązywała tylko do 30 września 1884 r., to

${ }^{10}$ Por. T. Müller: Der Geschichte der Breslauer Sozialdemokratie. Teil 2: Sozialistengesetz. Breslau 1925, s. 214, 216-217.

11 Por. ibidem, s. 208-218.

12 Gerhart Hauptmann. Pan na Jagniatkowie (1862-1946). Oprac. J. Koprowski, M. Misiorny. Warszawa 1996, s. 15.

${ }^{13}$ R. Loth: Młodość Jana Kasprowicza..., s. 118.

${ }^{14}$ Budzące duże wątpliwości okoliczności sprawy F. Herszela i udziału w niej L. Ciesielskiego przedstawia Leon Baumgarten: Dzieje Wielkiego Proletariatu. Warszawa 1966, s. $417-428$.

${ }^{15}$ R. Loth: Młodość Jana Kasprowicza..., s. 123.

${ }^{16}$ M. Sosnowski: Jan Kasprowicz..., s. 301.

17 T. Kulak: Historia Wrocławia. Od twierdzy fryderycjańskiej do twierdzy hitlerowskiej. Wrocław 2001, s. 253. 
jednak dalej działalność ugrupowań socjalistycznych zwalczano, odwołując się do postanowień ogólnoniemieckiego Kodeksu karnego z dnia 15 maja 1871 r. ${ }^{18}$.

Za pomoc udzieloną L. Ciesielskiemu przyjdzie J. Kasprowiczowi już w najbliższym czasie słono zapłacić. Policja bowiem, podążając tropem L. Ciesielskiego, dotarła także do J. Kasprowicza. Na razie jednak go zostawiła na wolności, kto wie, może myśląc, że J. Kasprowicz doprowadzi ją do innych osób. Za to władze uczelni, dowiedziawszy się o podejrzanych sprawach J. Kasprowicza, postanowiły interweniować. Dnia 27 kwietnia 1886 r. dyscyplinarny sąd uniwersytecki — za pomoc w ucieczce L. Ciesielskiego (konkretnie ,z powodu świadomego zaniedbania zameldowania policyjnego pomocnika mydlarskiego Leona Ciesielskiego") - skazał go na 30 marek grzywny z możliwością zamiany na trzy dni aresztu ${ }^{19}$. Niemający prawie nigdy pieniędzy J. Kasprowicz wybrał uniwersytecki karcer. „Jakoś się przeżyje - mówił do siebie - I przeżył. Przeżył nawet lepiej niż myślał. Ani chłodno nie było w celi, bo wiosna za oknami w całej pełni, ani głodno, bo skromny posiłek aresztancki zjadł bez marudzenia. Zresztą co miał marudzić? Całymi dniami nieraz głód oszukiwał, a tutaj jedzenie podali" ${ }^{20}$. Być może doświadczył on kuchni pani Kroll, żony pedla uniwersyteckiego Augusta Krolla, który nadzorował karcer, którzy mieli wręcz serdeczny stosunek do studentów odsiadujących karę karceru. Chwalono między innymi kuchnię pani Kroll i jej matczyny stosunek do „skazańców”, przez co zyskała sobie przydomek „Karcernej Mamy”21. Być może nawet tak jak to robili inni, zapisał jakiś wiersz w prowadzonej w tym czasie „Księdze karcernej"22.

Natomiast śledztwo prowadzone przez policję ciągle trwało. W związku z nim był parokrotnie wzywany przez nią na przesłuchanie ${ }^{23}$. Oprócz „spraw socjalistycznych" przyczyną zainteresowania policji osobą J. Kasprowicza była być może także jego działalność publicystyczna, jako korespondenta petersburskiego „Kraju” (ps. Piotr Huta) i lwowskiego „Przeglądu Społecznego” (ps. Franciszek Szyba), w której niejednokrotnie bardzo krytycznie pisał on o polityce i działaniach władz pruskich ${ }^{24}$.

18 Zbiór Praw Państwa Niemieckiego 1871, nr 24.

${ }_{19}$ Allgemeines Studenten-Register..., s. 89; M. Sosnowski: Jan Kasprowicz..., s. 312; R. Loth: Młodość Jana Kasprowicza..., s. 12.

${ }^{20}$ M. Sosnowski: Jan Kasprowicz..., s. 312.

${ }^{21}$ K. Popiński: Borussia, Lusatia, Marcomania... Świat burszów, piwiarń i pojedynków. Studenci Uniwersytetu Wrocławskiego 1871-1921. Wrocław 2002, s. 51-52.

${ }_{22}$ Por. J. Ressel: Das Karzerbuch der Breslauer Universität 1877-1886. „Breslauer Hochschul Rundschau" 1927, Jg. 18, Nr. 3, s. 33-36, s. 49-53. Księga ta niestety zaginęła, a w przywoływanym artykule są podane przykłady wierszy studentów, członków korporacji niemieckich do których nie należał J. Kasprowicz.

${ }^{23}$ M. Sosnowski: Jan Kasprowicz..., s. 321.

${ }^{24}$ T. Kulak: Historia Wroctawia..., s. 245 i 250. 
Dnia 15 marca 1887 r. został aresztowany H. Lux, u którego znaleziono dokumenty (korespondencję) świadczące o rzekomej przewrotowej działalności organizacji Pacyfic. Do niej także należał J. Kasprowicz, któremu grunt zaczął się palić pod nogami, czyniąc realnym groźbę aresztowania go. Dlatego też na wiosnę 1887 r. zlikwidował on swoje wrocławskie sprawy i wyjechał do Lwowa, do Bolesława Wysłoucha, gdzie podjął pracę w redakcji „Kuriera Lwowskiego”"25. Władze pruskie wysyłają jednak za nim listy gończe. Dla J. Kasprowicza listy te stanowiły „wilczy bilet”. Z ich powodu stał się osobą niemile widzianą we Lwowie, persona non grata. Policja austriacka nie wyraziła bowiem zgody na dalszy jego pobyt we Lwowie i jako cudzoziemcowi nakazała jego opuszczenie. Nie mając wyboru, został zmuszony do powrotu do Wrocławia, wiedząc, że czeka tam na niego proces polityczny, z którego, przypuszczał (czas pokazał, że było to błędne przypuszczenie - J.K.), że wyjdzie bez szwanku ${ }^{26}$.

Również 10 czerwca 1887 r. „,Z powodu niezaliczenia wykładów” (wegen Nichtannahme der Vorlesungen) został skreślony $\mathrm{z}$ uniwersyteckiego rejestru studentów ${ }^{27}$.

Na początku lipca 1887 r. po powrocie do Wrocławia stawił się w inkwizytoriacie (urzędzie śledczym) i po przesłuchaniu, po kilku dniach, kolejny raz został wypuszczony do domu. Żył w niepewności, denerwując się, co będzie dalej ${ }^{28}$.

Dnia 16 września 1887 r. do mieszkania J. Kasprowicza, przy Salzstraße 17 (Solna, dzisiejsza ul. Wojciecha Cybulskiego), na drugim piętrze ${ }^{29}$, wkroczyli żandarmi, dokonali rewizji, zarekwirowali papiery, dokumenty i trochę książek. Następnie J. Kasprowicz został aresztowany i osadzony w więzieniu wrocławskim. Był on jednym z 26 aresztowanych w tym dniu we Wrocławiu, podejrzanych o działalność socjalistyczną ${ }^{30}$. Fakt aresztowania wspomnianych osób odnotowała wrocławska prasa. Podobne aresztowania odbywały się w wielu miastach Niemiec (Berlinie, Gdańsku, Poznaniu) już od lipca 1887 r. Sprawa wrocławska była jedną z wielu rozpraw z socjaldemokratami. Początkowo różnym grupom osób aresztowanych w różnych okolicznościach zamierzano wytoczyć trzy oddzielne sprawy (choć na wspólnym tle politycznym). By jednak wstrząsnąć opinią ogółu, postanowiono połączyć wszystkie sprawy w jednym procesie, sporządzając dla nich wspólny akt oskarżenia. Objął on 38 podejrzanych o działalność socjalistyczną ${ }^{31}$.

${ }^{25}$ R. Loth: Młodość Jana Kasprowicza..., s. 135.

${ }^{26}$ M. Sosnowski: Jan Kasprowicz..., s. 352-353.

${ }^{27}$ R. Loth: Młodość Jana Kasprowicza..., s. 140.

${ }^{28}$ M. Sosnowski: Jan Kasprowicz..., s. 353.

${ }^{29}$ Być może krótko mieszkał on także we Wrocławiu przy Friedrichstrasse 14 (dzisiaj ul. Kolejowa), taki bowiem adres podaje on w liście do Adama Wiślickiego z dnia 25 czerwca 1885 r.; Jan Kasprowicz..., s. 68.

${ }^{30}$ R. Loth: Młodość Jana Kasprowicza..., s. 141.

${ }^{31}$ M. Sosnowski: Jan Kasprowicz..., s. 361-362. 
W „Wielkim socjalistycznym procesie” we Wrocławiu, który rozpoczął się w poniedziałek, dnia 7 listopada 1887 r., J. Kasprowicz znalazł się w gronie 34 wcześniej aresztowanych osób, które zasiadły na ławie oskarżonych. Byli wśród nich, między innymi: J. Kräcker (socjaldemokratyczny deputowany do Reichstagu), Bruno Geiser (poseł, publicysta, działacz socjaldemokratyczny, zięć Wilhelma Liebknechta), H. Lux (student matematyki), Julian Marcuse (student medycyny, znany J. Kasprowiczowi z Gimnazjum św. Marii Magdaleny w Poznaniu), Otto Matschocke (wytwórca guzików, irakijczyk), Paul Friedrich (tokarz), Paul Fläschel (wytwórca cygar), Hieronymus Naumann (Möbelpolierer), Josef Heisig (szewc), August Schönwald (wytwórca cygar), Emil Schwabauer (Metalldrucker), Wilhelm Zapke (ślusarz), Adolf Sturm (tokarz), Robert Wolf (Einleger), Oskar May (pomocnik mechanika), Paul Thiel (wytwórca cygar), Otto Haude (czeladnik stolarski), Oskar Kühnel (Eigarrenniacher), Otto Henschel (Stellmachergesellen), Paul Jungfer (tokarz), Heinrich Palatzky (czeladnik stolarski), Otto Pache (restaurator), Max Wertefrongel (Schriftgießer), Karl Hennemann (Stellmachergesellen), Karl Ulbrich (Maurerpolier), Gustav Heil (mistrz malarski), Anton Herrmann (murarz), Christian Maskos (czeladnik murarski), Otto Richter (Zigarrenmacher), Franz Holstein (Buchdrucker), August Buchmann (Strhhutpresser), Gustav Lübcke (stolarz), Max Zigan (Cigarrenmacherlehrling), nakładca Robert Conrad, Hermann Menzel (Kürschner) i Hermann Winkler (ślusarz) ${ }^{32}$. Oskarżeni podczas procesu przebywali $\mathrm{w}$ areszcie śledczym przy ul. Podwale ${ }^{33}$. W rzeczywistości przed sądem stanęło 37, a nie 38 oskarżonych, jednemu bowiem spośród nich - Augustowi Kühnowi ${ }^{34}$, udało się uciec do Szwajcarii ${ }^{35}$.

Najdłużej przebywał w więzieniu śledczym (od 7 marca) H. Lux. Następnie w połowie maja zostali aresztowani P. Fläschel, O. Kühnel i O. Matschocke; 18 czerwca, gdy opuszczał gmach parlamentu, został aresztowany poseł J. Kräcker, a 16 września reszta podsądnych (w tym J. Kasprowicz) ${ }^{36}$. Z wolnej stopy odpowiadał jedynie J. Marcuse. Karanymi wcześniej za przekroczenie ustawy socjalistycznej byli J. Kräcker i O. Kühnel ${ }^{37}$, G. Heil za obrazę majestatu, A. Herrmann za rozpowszechnianie zakazanych pism, a B. Geiser za naruszenie

32 T. Müller: Der Geschichte..., s. 233.

${ }^{33}$ T. Kulak: Historia Wrocławia..., s. 253; „Namslauer Stadtblatt”, 19.11.1887, Jg. 16, Nr. 91 , s. $3-4$.

${ }^{34}$ T. Müller: Der Geschichte...

35 „Gazeta Toruńska”, 12.11.1887, s. 3.

36 T. Müller: Der Geschichte..., s. 231-232.

${ }^{37}$ W lutym 1884 r. został on aresztowany za przemyt druków rewolucyjnych dla rosyjskiej organizacji Narodnaja Wola. Zaś rok wcześniej — w 1883, w swoim mieszkaniu przy Weisgerbergasse 26, ukrywał przebywającego we Wrocławiu L. Waryńskiego; L. Baumgarten: Dzieje..., s. 183, 252. 
porządku publicznego popełnione przez prasę. J. Kasprowicz i J. Marcuse byli jedynymi osobami stanu wolnego (nieżonatymi) w gronie oskarżonych ${ }^{38}$.

Proces rozpoczął się w poniedziałek, 7 listopada 1887 r., o godz. 9,00. Sprawa toczyła się przed I izbą karną sądu okręgowego (Landesgericht) we Wrocławiu. Przewodniczył prezes sądu okręgowego (Landgerichtsdirector) Otto Freytag ${ }^{39}$. Ponadto w skład kolegium sądzącego wchodzili radcowie sądu okręgowego (Landgerichtsräthen) Gäbe i Benno Großpietsch, sędzia sądu okręgowego (Landrichter) Max von Goldbeck ${ }^{40} \mathrm{i}$ asesor sądowy (Gerichts-Assessor) Friedensburg. W procesie oskarżał prokurator (Staatsanwalt) Max Nentwig ${ }^{41}$, którego asystentem był asesor sądowy Freiherrn Gotthard von Stillfried-Rattonitz ${ }^{42}$. Kasprowicz został zaliczony do kategorii oskarżonych szczególnie niebezpiecznych, którym zarzucono popełnienie czynów o szczególnej szkodliwości dla porządku publicznego, a konkretnie naruszenie $\S \S 128^{43}$ i $129^{44}$ ogólnoniemieckiego Kodeksu karnego. Chyba tylko dla pozoru prokurator na wstępie wystąpił, by $\mathrm{z}$ tego powodu utajnić rozprawę. Od razu było bowiem widoczne, że proces ma mieć pokazowy charakter ${ }^{45}$.

${ }^{38}$ Socialisten-Proceß. „Schlesische Zeitung” 1887, nr 780, s. 3; „Gazeta Toruńska”, 12.11.1887, s. 3.

${ }^{39}$ Znany wrocławski prawnik, radca sądowy Ernst Mamroth, pisał o nim w 1903 r.: „Freytag urobił wrocławskiemu wymiarowi sprawiedliwości opinię prawdziwego karnego batalionu [...]. Zawsze wydawał mi się w swej nieprzejednanej i bezlitosnej surowości i w swej purytańskiej pobożności naturą typu Cromwella”. R. Loth: Młodość Jana Kasprowicza..., s. 143; T. Müller: Der Geschichte..., s. 244.

${ }^{40}$ Urodził się on w 1844 r. Wcześniej był sędzią Amtsgerichtu w Goldbergu i Wrocławiu, a od 1890 r. był dyrektorem Amtsgerichtu w Legnicy, zaś od listopada 1896 r. prezydentem sądu okręgowego w Legnicy. Zmarł 21 sierpnia 1908 r. w następstwie nieszczęśliwego wypad$\mathrm{ku}$ (postrzału) na polowaniu. W Mierzowicach koło Legnicy (Merschwitz) znajduje się obelisk poświęcony jego pamięci.

${ }^{41}$ Wcześniej był prokuratorem w Opolu. Jego syn, także Max, był lekarzem wojskowym.

${ }^{42}$ Socialisten-Proceß..., s. 2.

${ }^{43} \S 128$. Uczestnictwo w związku, którego istnienie, ustawa lub cel mają przed rządem być trzymane $\mathrm{w}$ sekrecie, albo w którym względem nieznajomych przełożonych posłuszeństwo lub względem znajomych przełożonych bezwarunkowe się przyrzeka, ma na członkach być więzieniem do sześciu miesięcy, na fundatorach i przełożonych związku więzieniem od jednego miesiąca do jednego roku karanem.

Względem urzędników może utrata zdolności sprawowania urzędów publicznych na jeden do pięciu lat być wyrokowaną.

${ }^{4}$ § 129. Uczestnictwo $\mathrm{w}$ związku, do celów lub zatrudnień którego należy zapobieganie lub osłabianie nieprawnymi środkami kroków administracyi, lub wykonania ustaw, ma na członkach być więzieniem do jednego roku, na fundatorach i przełożonych związku więzieniem od trzech miesięcy do dwóch lat karanem.

Względem urzędników może utrata zdolności sprawowania urzędów publicznych na jeden do pięciu lat być wyrokowaną.

${ }_{45}$ M. Sosnowski: Jan Kasprowicz..., s. 362. 
W prasie proces określano jako ,proces socjalistyczny przeciwko studentowi Luxowi i towarzyszom" (Socialisteprocesses gegn den Studenten Lux und Genos$s e n)^{46}$. Takie postawienie sprawy, gdzie H. Luxa czyniono jednym z głównych bohaterów procesu, było niekorzystne dla J. Kasprowicza, który rzeczywiście był jednym z jego przyjaciół. Oskarżonych na sali rozpraw posadzono tak, by osoby znające się nie miały ze sobą kontaktu. J. Kasprowicz zasiadł na ławie oskarżonych obok mistrza malarskiego G. Heila i ślusarza H. Winklera ${ }^{47}$.

Kasprowicz, H. Lux i J. Marcuse stanowili odrębną grupę w tym procesie, zarzucono im przynależność i udział w młodzieżowej organizacji o charakterze socjalistycznym Pacyfik ${ }^{48}$. Główny założyciel tej organizacji - G. Hauptmann, uniknął aresztowania, szczęśliwie umykając przed policją do Szwajcarii. Roman Loth podaje, że występował on jednak w procesie J. Kasprowicza jako świadek $^{49}$. Ma rację R. Loth, G. Hauptmann stawił się bowiem na proces we Wroclawiu, uznał zarzuty stawiane swoim przyjaciołom za absurdalne i stanowczo zaprzeczył, by jego przyjaciele mieli zamiar dokonać przewrotu. Sąd z kolei zeznającego G. Hauptmanna potraktował jako szachraja, który także właściwie powinien był również znaleźć się na ławie oskarżonych ${ }^{50}$.

Działalność J. Kasprowicza, H. Luxa i J. Marcusa w Pacyfiku uznano za zamaskowaną formę działalności przewrotowej, polegającej na szerzeniu propagandy socjalistycznej. Wspomniany na początku L. Krzywicki uważał J. Kasprowicza „za anarchistę do szpiku kości”. Trzeba jednak dodać, że ocena ta odnosiła się do krótkiego okresu pobytu J. Kasprowicza na początku studiów w Lipsku w 1884 r. Bliższe prawdy, jeśli idzie o poglądy polityczne J. Kasprowicza szczególnie w okresie jego pobytu we Wrocławiu, było określenie, iż charakteryzowało go nastawienie utopijno-socjalistyczne, niewykluczające pewnych elementów anarchistycznych w ówczesnym jego światopoglądzie ${ }^{51}$. Prokurator konkretnie zarzucił J. Kasprowiczowi ,akcje konspiracyjno-wywrotową w duchu radykalno-socjalistycznym”, na co ten odpowiedział, że: „do winy się poczuwa, zeznając przy tym, iż jego działalność miała charakter na wskroś narodowy"52. J. Kasprowiczowi i H. Luxowi ponadto zarzucono udzielenie pomocy L. Ciesielskiemu, którego władze pruskie uznały za „niebezpiecznego agitatora” i pomoc jemu w ucieczce. Kasprowicz odnośnie sprawy L. Ciesielskiego złożył władzom policyjnym niezgodne z prawdą zeznania ${ }^{53}$.

\footnotetext{
${ }^{46}$ Socialisten-Proce $\beta \ldots$, s. 3.

47 R. Loth: Młodość Jana Kasprowicza..,, s. 142; T. Müller: Der Geschichte..,, s. 249.

48 T. Müller: Der Geschichte..., s. 207.

49 R. Loth: Młodość Jana Kasprowicza..., s. 121.

${ }^{50}$ Gerhart Hauptmann..., s. 17.

${ }^{51}$ Jan Kasprowicz..., s. 143, 324, przyp. 10.

${ }_{52}$ M. Sosnowski: Jan Kasprowicz..., s. 362, przyp. 356.

${ }^{53}$ R. Loth: Młodość Jan Kasprowicza..., s. 144; T. Kulak: Historia Wrocławia..., s. 253.
} 
W sumie w procesie przesłuchano 75 świadków. Jako świadków przesłuchano między innymi W. Liebknechta i Carla Grillenbergera. Świadkiem w procesie przeciwko J. Kasprowiczowi - oprócz G. Hauptmanna - był także pisarz Curt Baake ${ }^{54}$. Głównym obrońcą w procesie był berliński adwokat Munckel, któremu przydzielono do pomocy siedmiu adwokatów z Wrocławia ${ }^{55}$ (Martin Kirschner ${ }^{56}$, Isidor Ollendorf ${ }^{57}$, Cohn, Paul Hein, dr Max Berkowitz, Max Schreiber i C. Sternberg). Obrońcą J. Kasprowicza był M. Schreiber ${ }^{58}$. Większość adwokatów broniących oskarżonych w procesie wrocławskim była pochodzenia żydowskiego.

Dnia 17 listopada 1887 r. o godz. 12.00 został ogłoszony wyrok w procesie. Przewidywał on następujące kary pozbawienia wolności wobec oskarżonych: 1) J. Kräcker -7 miesięcy, 2) P. Friedrich -4 miesiące, 3) P. Fläschel -7 miesięcy, 4) H. Naumann - 3 miesiące, 5) J. Heisig - 2 miesiące, 6) A. Schönwald -3 miesiące, 7) E. Schwabauer - 4 miesiące, 8) W. Zapke -2 miesiące, 9) O. Matschocke - 6 miesięcy, 10) A. Sturm - 3 miesiące, 11) R. Wolf 3 miesiące, 12) O. Mai -2 miesiące, 13) P. Thiel -3 miesiące, 14) O. Haude -3 miesiące, 15) $\mathrm{O}$. Kühnel -5 miesięcy, 16) $\mathrm{O}$. Henschel -1 miesiąc, 17) P. Jungfer -2 miesiące, 18) H. Palatzky -3 miesiące, 19) O. Pache 2 miesiące, 20) M. Wertefrongel -2 miesiące, 21) K. Hennemann -2 miesiące, 22) K. Ulbrich - 1 miesiąc, 23) G. Heil - 3 miesiące, 24) A. Herrmann 3 miesiące, 25) G. Lübke -2 miesiące, 26) M. Zigan -6 tygodni (gdyż był niepełnoletni, ur. 27.01 .1869 r., czyli miał 18 lat 10 miesięcy), 27) H. Lux 1 rok, 28) J.J. Marcuse -4 miesiące, 29) J. Kasprowicz -6 miesięcy $^{59}$.

Po ogłoszeniu wyroku większość zasądzonych nie została uwięziona. Jedynie trzech skazanych - O. Matschocke, H. Luxa i J. Kasprowicza - w mniemaniu sądu najbardziej niebezpiecznych, osadzono natychmiast w więzieniu ${ }^{60}$.

Kasprowicz karę 6 miesięcy więzienia, na jaką został skazany, odbywał na przełomie roku $1887 / 1888^{61}$. Odsiadywał ją w więzieniu przy ul. Podwale Świdnickie, którego dyrektorem był Teodor Grützmacher, cieszący się opinią człowieka uczciwego i nienadużywającego swej władzy. Potwierdzeniem tego są słowa listu z więzienia J. Kasprowicza, w którym pisze: „Czas schodzi jako tako,

${ }^{54}$ R. Loth: Młodość Jan Kasprowicza..., s. 122; T. Müller: Der Geschichte..., s. 246, 253.

55 T. Müller: Der Geschichte..., s. 244.

${ }^{56}$ M. Kirschner (1842-1912), członek Niemieckiej Partii Postępu (Deutsche Fortschrittspartei), od czerwca 1898 r. nadburmistrz Berlina.

${ }^{57}$ I. Ollendorf (1855-1911), od 1890 r. deputowany do Zgromadzenia Radnych Miejskich Wrocławia. Mąż Pauli Ollendorf, pierwszej w historii Niemiec kobiety, która została wybrana radną.

${ }_{58}$ Socialisten-Proce $\beta, \ldots$ s. 2 -3.

${ }^{59}$ Ibidem, s. 3; „Namslauer Stadtblatt”, 19.11.1887, s. 3-4.

${ }^{60}$ R. Loth: Młodość Jana Kasprowicza..., s. 144-145.

${ }^{61}$ T. Kulak: Historia Wroctawia..., s. 253. 
urzędnicy obchodzą się z nami przyzwoicie"62. Więzienie opuścił 17 maja $1888 \mathrm{r}$. W sumie w więzieniu przesiedział on 8 miesięcy, prośba bowiem J. Kasprowicza o zwolnienie z aresztu do czasu rozprawy została odrzucona. Sąd także nie zaliczył mu na poczet orzeczonej kary aresztu śledczego ${ }^{63}$. Wyszło prawie na to, co żądał prokurator, który wnosił odnośnie J. Kasprowicza karę dziewięciu miesięcy więzienia, proponując jednocześnie zaliczenie aresztu śledczego ${ }^{64}$.

Pierwsze tygodnie J. Kasprowicz w więzieniu spędził w pojedynczej celi, wpłynęło to na niego przygnębiająco, ale za to miał możliwość pracy twórczej. Odzwierciedlenie jego stanu psychicznego w tym okresie znajdujemy w napisanym w tym czasie sonecie $Z$ więzienia, w którym odnosił się on do swojego nieprzyjemnego położenia; czy też poemacie Chrystus, w którym stawiał pytanie „o sens istnienia Boga, sens Chrystusowej ofiary wobec istnienia niezmiennego, niezniszczalnego zła na świecie?" ${ }^{65}$. W styczniu 1888 r. został przeniesiony do zbiorowej celi. W czasie odbywania kary J. Kasprowicz pracował, zarabiał w ten sposób pieniądze na kupno najbardziej potrzebnych rzeczy. Wspierał go także Stefan Suchocki (student agronomii, u którego mieszkał przed aresztowaniem, a także jego świadek na ślubie z Teodozją Szymańską), który dowiedziawszy się o jego skazaniu, dostarczył mu zimowe ubranie, bieliznę, różne drobiazgi, papier i jedną markę tygodniowo ${ }^{66}$.

Wrocławski proces w życiu J. Kasprowicza miał przełomowe znaczenie. Z punktu widzenia prawa karnego, gdzie odnośnie celów kary mówi się o prewencji indywidualnej, czyli oddziaływaniu kary na sprawcę przestępstwa. Można powiedzieć, że miał stuprocentową skuteczność. Po tym bowiem procesie J. Kasprowicz odpuścił sobie wszelką działalność polityczną, zamknął za sobą okres żywych przejściowych sympatii socjalistycznych i skupił się na tym, w czym był najlepszy, z czego przeszedł do historii, czyli na poezji.

Wydarzenia roku 1887, a zwłaszcza skreślenie z listy studentów uniwersytetu we Wrocławiu i wyrok skazujący przekreśliły także plany J. Kasprowicza doktoryzowania się i ewentualnej dalszej pracy naukowo-dydaktycznej ${ }^{67}$.

Mimo że J. Kasprowicz więzienie opuścił w połowie maja, z Wrocławia wyjechał dopiero pod koniec roku 1888, ale tym razem już na zawsze. Od 1889 r. J. Kasprowicz związał się na prawie trzydzieści lat ze Lwowem, w którym znalazł oparcie po trudnych i burzliwych latach uniwersyteckich ${ }^{68}$.

\footnotetext{
${ }^{62}$ R. Loth: Młodość Jana Kasprowicza..., s. 145-146.

${ }^{63}$ M. Sosnowski: Jan Kasprowicz..., s. 361.

${ }^{64}$ R. Loth: Młodość Jana Kasprowicza..., s. 144.

${ }^{65}$ Jan Kasprowicz..., s. 21, 72.

${ }^{66}$ R. Loth: Młodość Jana Kasprowicza..., s. 146, 150.

${ }^{67}$ M. Sosnowski: Jan Kasprowicz..., s. 333.

${ }^{68}$ Jan Kasprowicz..., s. 12-13, 49.
} 


\section{Bibliografia}

Album der mit dem Zeugniss der Reife in der Philosophischen Fakultaet inscripten Studierenden, 23 IV 1885-28 X 1911. Archiwum Uniwersytetu Wrocławskiego, sygn. 435.

Allgemeines Studenten-Register Philosophische Fakultät. Abgegangene Studenten. Vol. XXXIII. Archiwum Uniwersytetu Wrocławskiego, sygn. F 479.

Zbiór Praw Państwa Niemieckiego 1871, nr 24.

Baumgarten L.: Dzieje Wielkiego Proletariatu. Warszawa 1966.

Gerhart Hauptmann. Pan na Jagniatkowie (1862-1946). Oprac. J. Koprowski, M. Misiorny. Warszawa 1996.

Jan Kasprowicz. Wstęp, wybór materiałów i przypisy R. Loth. Warszawa 1964.

Koredczuk J: Studia Andrzeja Szeptyckiego we Wroctawiu. W: Śląska Republika Uczonych. Schlesische Gelehrtenrepublik. Slezska Védecká Obec. Red. M. Hałub, A. Mańko-Matysiak. T. 5. Dresden-Wrocław 2012.

Kulak T.: Historia Wrocławia. Od twierdzy fryderycjańskiej do twierdzy hitlerowskiej. Wrocław 2001.

L oth R.: Młodość Jana Kasprowicza. Szkic biograficzny. Poznań 1962.

Müller T.: Der Geschichte der Breslauer Sozialdemokratie. Teil 2: Sozialistengesetz. Breslau 1925.

Popiński K.: Borussia, Lusatia, Marcomania... Świat burszów, piwiarń i pojedynków. Studenci Uniwersytetu Wrocławskiego 1871-1921. Wrocław 2002.

Ressel J.: Das Karzerbuch der Breslauer Universität 1877-1886. „Breslauer Hochschul Rundschau” 1927, Jg. 18, Nr. 3; „Breslauer Hochschul Rundschau” 1927, Jg. 18, Nr. 4.

Socialisten-Proceß. „Schlesische Zeitung” 1887, Nr. 780.

Sosnowski M.: Jan Kasprowicz. Opowieść biograficzna. Cz. 1: Chłopska sukmana (1860-1889). Zakopane 2015.

Sosnowski M.: W zgodzie z bytem i przeznaczeniem. Rozważania o osobowości Jana Kasprowicza. Psychologiczny portret twórcy. Warszawa 2010.

Szeptycka Z.: Młodość i powołanie ojca Romana Andrzeja Szeptyckiego zakonu św. Bazylego Wielkiego. Wrocław 1993.

Wójtowicz S.: Wrocławskimi śladami metropolity Andrzeja Szeptyckiego. „Acta Universitatis Wratislaviensis" 2012, nr 3459. Slavica Wratislaviensa, T. 156.

„Gazeta Toruńska”, 12.11.1887.

„Namslauer Stadtblatt”, 19.11.1887. 
Józef Koredczuk

\section{Prozess von Jan Kasprowicz in Breslau im Jahre 1887}

Schlüsselwörter: sozialistische Tätigkeit, Jan Kasprowicz, Organisation Pacyfik, Sozialdemokratie, Breslau

Zusammenfassung: Jan Kasprowicz übte beim kurzen Aufenthalt in Breslau während seines Studiums auch eine äußerst aktive politische Tätigkeit aus. Sie hing mit seiner Teilnahme an der Organisation Pacyfik zusammen, die mit der deutschen Sozialdemokratie verbunden war. Aus diesem Grund wurde er festgenommen und in einem der größten Verfahren in Deutschland, die auf der Grundlage antisozialistischer Gesetze durchgeführt wurden, vor Gericht gestellt. Da er ein Pole war, wurde er 1887 in Breslau zu einer der schwersten Strafen im Prozess verurteilt. Die Zeit, in der Jan Kasprowicz in Breslau weilte, war eine der schwierigsten in seinem Leben. Unter Einfluss der Erfahrungen aus Breslau gab er schließlich seine politische Tätigkeit auf und begann sich ausschließlich mit dem literarischen Schaffen zu befassen.

Józef Koredczuk

\section{The trial of Jan Kasprowicz in Wroclaw in $\mathbf{1 8 8 7}$}

Keywords: socialist activity, Jan Kasprowicz, organisation "Pacyfik", social democracy, Wrocław

Summary: During his short stay in Wrocław in the course of his studies, Jan Kasprowicz was also very active in politics. It was connected with his participation in the organisation called "Pacyfik" ["Pacific"], which was associated with German social democracy. For this reason, he was arrested and tried in one of the largest trials in Germany performed on the basis of anti-socialist laws. Due to the fact that he was a Pole, he received one of the most severe sentences in the trial in Wrocław in 1887. Jan Kasprowicz's stay in Wrocław was one of the most difficult periods in his life. As a result of the Wrocław experience, he finally gave up political activity and took up exclusively literary activities. 